\section{The Future of our British Flora}

I MUCH fear that the botanists of 1977 , when roaming in search of specimens, will find it much more difficult to collect a varied herbarium, and that the poets of that period will be unable to obtain gratification from the sight of many interesting and beautiful plants which are already fast becoming rare and in a short period will likely be extinct with us.

Indeed the very curiosity to learn something more about botany, the teaching of which is now included as a "special subject" in our elementary schools, laudable as it is, has a tendency to hurry forward the extinction of rare forms, the collecting and recognising of which is almost a passion with beginners and much preferred to the slower and more instructive work of becoming thoroughly acquainted with what is common or widely diffused.

A few reminiscences culled from my experience will make plain what I mean. No one who has paid attention to the flora around a great and fast-increasing city such as Glasgow but must be struck with the extinction, in twenty or thirty years, of almost everything that used to be rare in the country district around. Showy flowers, such as the great mullein and the foxglove, are the first to suffer. They are like the large game in a newlycolonised country. In vain you look for them on the wayside of any well-macadamised road. They possess the fatal gift of beauty, and are either rooted out to perish miserably in a smoky garden, or destroyed from mere wantonness. A few days ago 1 visited the romantic ruins of Crookston Castle, about four miles from Glasgow, but I looked in vain for the common arum which, being rare in Scotland, made a visit to the ruins still more interesting when it flourished there healthily about twenty years ago.

In one single spot in Renfrewshire did I know of the existence of a few plants of the lizard orchis, but on making to see them after a long absence, I learned that the very last plant had been rooted and taken off this season by a schoolmaster eager to teach his pupils botany. Indeed, when an Edinburgh professor's class was about to visit a well-reputed floral locality this summer, I went to the farmer upon whose grounds the bird's-nest orchis grew, and implored him that, when the Hiving wave passed by, he was not to betray to any student that alone in a wide distric he was the possessor of so rare a treasure, and I believe my salutary warning prevented it from being all dug out.

In my own parish the walline spleenwort is represented by a single plant, and on the walls of a castle in a neighbouring district it grows no further down than human lands can reach. Even such common ferns as the royal csmund, the green spleenwort, and the parsley fern are completely lost to some districts within my recollection, and many of your readers could give other instances to the same point.

Will the flora of the future then tend to a dull uniformity so that only a limited number of widely-diffused species shall carpet the earth? To neutralise this tendency we have no doubt many escaped garden plants which in process of time get established on our waysides and unoccupied spaces. I have even known the case of the successful introduction of wild flowers formerly unknown to a district, and in my own parish I was pleasantly surprised to find, well-established in one locality, the field allium, the seeds of which had been sown by a friend, who obtained it in Sussex, many years ago.

Tynron, Dumfriesshire

\section{The Towering of Wounded Birds}

IT is still supposed by some sportsmen and gamekeepers that the towering of a wounded bird is caused by an injury to its head. In some instances this may possibly be the case, if the lesion of the brain be not so severe as to cause instant death more generally, however, towering seems to be the result of internal hæmorrhage and asphyxia. In the unconscious condition produced by the circulation of venous blood the bird rises as it continues to fly, and at last falls dead.

The-following is a good example of this mode of death; it occurred a few days ago in the case of a partridge. I made a careful examination of the bird, and found a condition that confirmed the explanation that towering is due, not to injury to the head, but to internal bremorrhage and its consequences:-

On October 2 a partridge (it was an old male bird) was fired at at about forty yards. The bird flew about 450 yards after being hit, then towered high, and fell ; it was picked up at about five poles, quite dead.
I examined it early next day; the feathers were all carefully removed. There was a slight wound in the neck; a pellet of No. 2 shot had perforated the skin, but had not penetrated or injured the subjacent tissues. There was a wound in the right pectoral muscle ; the pellet had penetrated very slightly, and lay under the integument.

Two pellets had penetrated the abdominal cavity, one through the abdominal wall, the other through the bone. Both had passed forwards; one had slightly wounded, but not perforated, the stomach, and had then passed through the right lung; a large vessel had been divided. There was much blood clot in the cavity, and both lungs were congested and also collapsed.

On examining the trachea it was found that there were three blood clots-one near the bifurcation, a second about an inch above it, which firmly plugged the tube; a third, smaller, near the larynx. There was a small blood clot in the mouth and œsophagus-swallowed blood.

The heart and liver were uninjured, the brain was "carefully examined ; there was no injury ; it was quite healthy and normal, except that the surface of the cerebellum had some slightiy congested vessels. The spinal cord was uninjured; death caused by asphyxia and hæmorrhage. As the subject has been previously discussed, this case may be of sufficient interest for insertion in NATURE,

The pursuit of sport gave an opportunity of elucidating a point of some physiological interest that might not have been permitted to that of science.

J. FAYRER

\section{Meteors}

ON Tuesday evening, October 2, at 8.59 P.M., whilst watching for shooting stars, I saw a fine meteor. At first scarcely brighter than a first magnitude star, it suddenly increased to the apparent size of Venus when about three parts of its path had been traversed, and then it appeared to explode with remarkable brilliancy. The motion was rather slow, and just in the place where its maximum was attained, it left a short luminous streak that I could trace as a faint nebulous patch on the sky for about three and a half minutes, drifting some five degrees away from the place it first occupied, and gradually dying out until I finally lost it amongst the small stars of Cassiopeia. It had moved from R.A. $34^{\circ}$, Dec. $57^{\circ}$ N. to R.A. $352^{\circ}$, Dec. $54^{\circ} \mathrm{N}$. The position of the meteor's course as I observed it was from the star $\beta$ Cepiei to the direction of (and below) a Andromedre.

On the following night, Octobsr $3,8 \cdot 3^{8}$ x.M, another large meteor was observed here, falling with a very swift, short path a few degrees to the right of the Pointers in Ursa Major. It must have been as bright as Venus, for it gave a strong flash in a very foggy condition of the atmosphere. There was a bright streak left in its track for about fifteen seconds.

A third meteor, far brighter than either of the two preceding, was recorded on Monday, October 8, at II'50 P.M., and estimated to be twice as brilliant as Venus. Its path was nearly vertical, close to the eastern horizon, and probahly directed from a radiant near $B$ Tauri, at R.A. $77^{\circ}$, Dec. $31^{\circ} \mathrm{N}$. The sliy was brightly illuminated with its intense lustre at the moment of appearance. There was a short streak visible for three seconds, and this, as in the two previous cases, served accurately to indicate the direction of its path.

The following were the exact courses of these large meteors and of a few others seen recently by me :-

\begin{tabular}{|c|c|c|c|c|c|c|c|c|}
\hline Qat & 1877 & Time. & & Mag. & $\begin{array}{c}\text { Began } \\
\text { R.A. Dec. } \\
0 \quad 0\end{array}$ & $\begin{array}{c}\text { Ended. } \\
\text { C. A. Ucc. } \\
0 \quad 0\end{array}$ & Path. & Notes. \\
\hline ept. & I5 $\cdots$ & $1.22 \mathrm{Y}$ & $\ldots$ & 24 & ... $56 \pm 0$. & ... $55-6$ & $\ldots \sigma$ & $\begin{array}{l}\text { eak } 4 \text { sec., } \\
\text { rapid. }\end{array}$ \\
\hline ", & $\begin{array}{ll}16 & \ldots\end{array}$ & $\begin{array}{l}1530 \\
1442\end{array}$ & $\cdots$ & $\frac{41}{2 !}$ & $\begin{array}{cc}\ldots & 139+78 . \\
\ldots & 73+5 .\end{array}$ & $\begin{array}{l}\ldots \quad 2 S_{2}+87 \\
\ldots \quad 60-5\end{array}$ & $\begin{array}{ll}\ldots & x_{5} \\
\ldots & 16\end{array}$ & $\begin{array}{l}\text { reak, rapid. } \\
\text { reak, rapid. }\end{array}$ \\
\hline Oct. & $2 \ldots$ & 859 & $\ldots$ & $q$ & ... $325+67$. & a. $354+4^{8}$ & ... 24 & $\begin{array}{l}\text { edk } 3 \frac{1}{3} \text { min., } \\
\text { slowish. }\end{array}$ \\
\hline " & $2 \ldots$ & 946 & $\ldots$ & If & ... $203+40$. & ... $198+3^{6}$ & $\ldots$ & Slow. \\
\hline " & $3 \cdots$ & $83^{3}$ & $\therefore$ & $q$ & ... I $55+64$. & ... I $_{52}+55$ & $\cdots \mathrm{I}$ & $\begin{array}{l}\text { eak Is sec, } \\
\text { rapid. }\end{array}$ \\
\hline " & $7 \ldots$ & 9 I4 & $\cdots$ & $2 !$ & ... 3rot 60. & .. $3^{\text {I } 9}+55^{\frac{1}{3}}$ & $\ldots \quad \sigma_{2}$ & $\begin{array}{l}\text { ow streak, } \\
\text { ear radiant. }\end{array}$ \\
\hline ", & $\& \ldots$ & II 50 & $\cdots$ & $2 \times q$ & ... rogtry. & $\ldots x x_{6}+r_{2}$ & $\cdots$ & \\
\hline "' & $8 \ldots$ & 1335 & $\cdots$ & $7 !$ & … $46+50$. & ‥ $346+32$ & ... 47 & $\begin{array}{l}5^{2} \text {, not } \\
\text { d. }\end{array}$ \\
\hline " & I5 $\ldots$ & 1625 & $\cdots$ & u & .. $232+83$. & ... $2 \sqrt{3}+76$ & $\cdots$ & \\
\hline " & r6 ... & I3 18 & $\cdots$ & 4 & ... $105+39$. & $\cdots x=6+50$ & $\ldots I_{3}$ & $i^{3}$ sec. \\
\hline " & $\begin{array}{ll}17 & \ldots \\
18 & \ldots\end{array}$ & $\begin{array}{l}1628 \\
1638\end{array}$ & $\begin{array}{l}\ldots \\
\cdots\end{array}$ & 34 & $\begin{array}{l}\ldots 50+54 . \\
\ldots \quad 26+43 .\end{array}$ & $\begin{array}{rr}\ldots & x 86+56 \\
\cdots & 1+4 x\end{array}$ & $\begin{array}{ll}\ldots & 20 \\
\ldots & 19\end{array}$ & $\begin{array}{l}\text { Streak, rapid. } \\
\text { Streak, rapid. }\end{array}$ \\
\hline
\end{tabular}

